\title{
KAJIAN HASIL PENELITIAN EMPIRIS HUBUNGAN KINERJA KEUANGAN, STRATEGI INOVASI, BIAYA MODAL DAN KINERJA PASAR TERHADAP CORPORATE SOCIAL PERFORMANCE
}

\author{
Sri Pujiningsih \\ Jurusan Akuntansi Fakultas Ekonomi Universitas Negeri Malang \\ Email: sripujiningsih@um.ac.id
}

\begin{abstract}
This article aims to review empirical research results of corporate social performance (CSP) themes. This article will discuss, firstly, the relationship of financial performance and CSP, the relationships of both are negative, positive and no correlation, based on difference theories. Secondly, the correlation of innovation strategy and CSP are explained by signaling theory. Thirdly, the correlation of cost of capital and CSP can be illuminated by good management theory. Fourth, correlation of market performance and CSP can be explained by signaling and good management theory. The advantages of this article can guide researchers to developed theoretical framework and hypothesis.
\end{abstract}

Key words: CSP, financial performance, innovation strategy, cost of capital, market performance

\section{PENDAHULUAN}

Hasil penelitian di Indonesia mengenai hubungan antara Corporate Social Performance (CSP) atau biasa disebut CSP dan Corporate Financial Performance (CFP) menunjukkan hasil yang tidak konsisten. Hasil penelitian yang menunjukkan bahwa keduanya tidak berhubungan (Sembiring, 2005; Anggarini, 2006; Fauzi, 2007, Pujiningsih, 2009). Berbeda dengan hasil penelitian Rofelawati (2010) yang menyatakan bahwa terdapat hubungan positif antarkeduanya. Sementara untuk ukuran perusahaan yang diproksi dengan total aset,untuk keseluruhan penelitian tersebut menunjukkan hubungan yang positif antara size dengan CSP.

Berkaitan dengan posisi keuangan yang merupakan diterminan perusahaan yang melakukan pengungkapan CSP, menurut Paul \& Siegel (2006) bahwa CSP mungkin akan berpengaruh terhadap efisiensi, perubahan teknik dan skala ekonomi juga akan berpotensi meningkatkan outsourcing serta pengurangan tenaga kerja dan investasi. Selain itu bahwa motivasi manajer dalam melakukan pengungkapan sosial bergantung pada undang-undang pajak, lokasi, umur aktiva tetap serta aktivitas inovasi. Aktivitas inovasi biasanya dikaitkan dengan investasi R\&D. 
Pengungkapan yang dilakukan oleh perusahaan seharusnya memberikan manfaat untuk pengurangan biaya modal. Hal ini dengan alasan bahwa peningkatan pengungkapan akan mengurangi biaya transaksi untuk investor, karena tingkat likuiditas yang lebih besar dalam pasar serta lebih besarnya permintaan atas surat berharga perusahaan (Diamond \& Verrecchia, 1991). Selain itu pengungkapan akan mengurangi risiko dan ketidakpastian return saham, demikian hasil penelitian Clarkson,Guedes, \& Thompson, 1996 ( Richardson dan Welker,2001).

\section{Hubungan Corporate Financial Performance (CFP) dan Corporate Social performanace} (CSP).

Terdapat perdebatan manakah hubungan yang lebih mendahului antara CSP dengan CFP. Penelitian Scholtens (2008) menunjukkan bahwa dengan menggunakan model lagged OLS dan Granger causation, maka hubungan sebab akibat antara CSP dengan CFP, berawal dari CFP baru kemudian CSP. Hasil penelitian di Indonesia mengenai size sebagai diterminan CSP dapat juga dijelaskan dengan hasil penelitian ini. CFP yang diukur dengan ROA sangat bergantung pada size (total aset). Dengan demikian posisi keuangan (size) dapat dijadikan faktor penentu awal untuk model pengungkapan sosial di Indonesia. Berikut ini disarikan mengenai hubungan antara kedua variable tersebut.

\section{Hubungan Negatif}

Penelitian hubungan kausal antara CSP dan CFP dilakukan di Kanada oleh Makni et.al (2008) menunjukkan bahwa tidak terdapat hubungan yang signifikan antara keduanya, kecuali untuk return saham. Terdapat hubungan negatif signifikan antara CSP dan CFP yang diproksi dengan ROA, ROE dan return pasar. Hal ini menunjukkan bahwa perusahaan dengan semakin tinggi tingkat CSP maka semakin rendah tingkat profitabilitasnya. Oleh karena sebagain sumber daya perusahaan diinvestasikan untuk kegiatan CSP.

Sementara menurut trade-off hypothesis menjelaskan hubungan negatif antara CSP dan CFP. Hipotesis ini dikembangkan dengan mendasarkan pada pemikiran teori ekonomi neo klasik. Dari pandangan teori ini dijelaskan bahwa aktivitas sosial akan mengurangi kesejahteraan pemegang saham dan mengurangi laba perusahaan( Waddock and Graves,1997). Pemikiran hipotesis ini lebih banyak dipengaruhi oleh pemikiran Milton friedman yang menyatakan bahwa tujuan utama perusahaan adalah untuk meningkatkan profitabilitas (1970). Hal ini diperkuat dengan hasil penelitian Vance (1975) yang menunjukkan bahwa tingkat pengungkapan yang tinggi akan mempengaruhi penurunan harga saham relatif terhadap rata-rata pasar (Preston and O'Bannon, 1997). Menurut 
hipotesis ini dalam kaitannya dengan aktivitas pasar modal dapat dijelaskan bahwa terdapat hubungan negatif antara tingkat pengungkapan sosial dengan harga saham.

Berbeda dengan trade off hypothesis, menurut the managerial opportunism hypothesis, manajer akan memperlakukan aktivitas sosial sesuai kepentingannya. Ketika kinerja keuangan meningkat maka manajer akan mengurangi pengeluaran untuk aktivitas sosial untuk memaksimalkan kesejahteraannya. Sebaliknya ketika kinerja keuangan perusahaaan menurun makan manajer melakukan sebaliknya untuk menutupi kekecewaan atas penurunan laba (Preston and O'Bannon, 1997). Hipotesis ini dikembangkan menggunakan teori akuntansi positif yang mendasarkan pada teori keagenan, dalam kitannya dengan bonus plan. Dengan rencana bonusnya maka manajer akan mengabaikan aktivitas sosial yang dapat mempengaruhi pengurangan laba yang akan dijadikan dasar bagi kompensasinya. Dengan demikian menurut hipotesis ini bahwa kinerja keuangan berhubungan negatif dengan kinerja sosial

Positive synergy hypothesis menjelaskan bahwa kinerja sosial yang kebih tinggi akan meningkatkan kinerja keuangan, dengan menginvestasikan sumber daya perusahaan untuk aktivitas sosial (Allouche and Laroche, 2005a). CSP yang baik akan mendorong ketersediaan dana (social impact hypothesis) yang akan dialokasikan lagi untuk stakeholder yang berbeda (slack resources hypothesis). Pandangan sinergi hipotesis ini dapat digunakan untuk menjelaskan hubungan CSP dan CFP adalah merupakan hubungan interaktif positif (Makni et,al,2008). Sebaliknya dengan mendasarkan pada hipotesis sinergi negatif, maka dapat dijelaskan bahwa semakin tinggi CSP maka akan mempengaruhi penurunan CFP. Dengan penurunan CFP maka ketersediaan dana untuk aktivitas sosial lebih lanjut menjadi terbatas. Hubungan keudanya menjadi hubungan interaktif negatif.

Freedman and Wasley (1990) menunjukkan bahwa pengungkapan lingkungan tidak menunjukkan kinerja lingkungan yang sebenarnya. Bewley and Li (2000) melakukan penelitian di Kanada menemukan hubungan yang negatif antara kinerja lingkungan dan pengungkapan lingkungan. Hal ini sesuai dengan pendapat yang dikemukakan Milton Friedmen, jika perusahaan lebih, mejmentingkan pegeluarkan biaya untuk CSP dibandingkan untuk pencapaian laba, maka hal ini akan berdampak pada indikator kinerja keuangan yang menurun. tambahan biaya tenaga kerja maupun untuk stakeholder lain akan meningkatkan biaya.

Pandangan lain mengatakan bahwa terdapat hubungan negatif antara kinerja lingkungan dan kinerja ekonomi dengan mendasarkan pada teori politik sosial khususnya teori legitimasi. Ketika peusahaan melakukan pengungkapan sebagai strateginya untuk 
menyelamatkan perusahaan atas ancaman legitimasi, maka perusahaan akan meningkatkan pengungkapan lingkungan dan sosial. Berdasarkan pendapat Gray, Kouhy, and Lavers (1995) and Lindblom (1994) bahwa pengungkapan lingkungan dilakukan untuk mengubah ekspektasi publik, mengubah persepsi publik dan menunjukkan informasi yang lebih mengenai kinerja perusahaan. Teori legitimasi menurut Patten $(2000,2002)$ menjelaskan hubungan negatif antara kinerja keuangan dan kinerja lingkungan.

\section{Hubungan Positif}

Hubungan positif antara CFP dengan CSP dijelaskan oleh Waddock \& Graves, (1997) yang menyatakan jika perusahaan tidak berperilaku etis dan bertanggung jawab, dengan mencoba untuk mengurangi kos pertanggungjawaban sosial maka dalam jangka panjang perusahaan akan tidak akan mendapatkan manfaat berkelanjutan. Selain itu CSP dianggap sebagai Good Management yang akan meningkatkan hubungan dengan stakeholder dan dalam waktu yang sama akan meningkatkan kinerja secara keseluruhan. Alasan berikutnya, dengan mendasarkan pada theory of scarce resources, bahwa perilaku CSP merupakan suatu konsekuensi dan bukan suatu sebab dari peningkatan kinerja. Ketika perusahaan memiliki sumber daya yang lebih besar maka sebaiknya dialokasikan untuk aktivitas semacam CSP,

Sejalan dengan pernyataan Preston \& O'Bannon (1997) mengenai ketersediaan sumber dana, sebagai faktor yang menentukan perilaku manajer. Teori good management juga bisa disebut sebagai hipotesis social impact, dimana kinerja keuangan yang lebih baik akan diikuti reputasi perusahaan yang lebih kuat. Dengan kata lain, pencapaian peningkatan reputasi perusahaan berhubungan erat dengan peningkatan kinerja keuangan. Sebaliknya kegagalan perusahaan dalam merespon kebutuhan stakeholder akan meningkatkan ketidakpastian pasar, meningkatkan risiko investasi, meningkatkan biaya dan berpotensi menimbulkan kerugian.

Selain teori good management, dengan mendasarkan pada teori stakeholder maka terdapat hubungan positif antara CF dan CSP. Dengan memenuhi kepentingan berbagai kelompok stake holder maka akan berdampak positif terhadap kinerja keuangan perusahaan (Freeman, 1984). Dengan demikian reputasi perusahaan akan berdampak pada kinerja keuangan. Sebaliknya jika perusahaan mengecewakan kelompok stakeholder maka akan berdampak negatif pada kinerja finansial perusahaan (Preston \& O’Bannon,1997).

Selanjutnya, Slack resource hypothesis memprediksikan bahwa lebih baik potensi kinerja keuangan digunakan untuk meningkatkan investasi untuk tanggung jawab sosial 
terutama dalam hal komunitas sosial, hubungan ketenagakerjaan atau lingkungan (Waddock and Graves, 1997). Dari hipotesis ini dapat dijelaskan bahwa tanggung jawab sosial dimulai dari ketersediaan sumber daya perusahaan atau kinerja keuangan. Dengan demikian kinerja keuangan akan mempengaruhi kinerja sosial. Beberapa penelitian menunjukkan bahwa terdapat hubungan positif antara ukuran perusahaan yang diproksikan dengan total aset terhadap kinerja sosial perusahaan di Indonesia (Pujiningsih, 2009; Sembiring, 2006). Hal ini menunjukkan bahwa semakin besar aset yang digunakan perusahaan dalam kegiatan perusahaan maka aka semakin meningkatkan aktivitas sosial perusahaan.

Penelitian lain yang dilakukan dengan pendekatan meta analisis oleh Allouche \& Laroche (2005; Orlitzky et. al (2003); dan Wu (2006); Makni(2008) menunjukkan hubungan positif antara CFP dengan CSP. Sementara hibungan timbal balik antarkeduanya dilakukan oleh Waddock Graves (1997) Hillman and Keim (2001) yang menemukan hubungan timbal balik positif. Nelling and Webb (2006) menguji hubungan kasusal antara CSP dengan CFP dengan menggunakan pendekatan ekonometrik, granger causality approach. Namun hasil penelitian ini menyarankan penggunaan model regresi ordinary least square (OLS). Hasil penelitian ini menunjukkan hubungan yang lemah antarkeduanya ketika menggunakan pendekatan time series. Selanjutnya hasil yang sama ditemukan pada pendekatan granger casuality model. Untuk kinerja CSP individu perusahaan menemukan hubungan kasual kinerja pasar saham dengan CSP terutama untuk item tenaga kerja. Sementara penelitian di Amerika menunjukkan hasil yang berbeda antara CSP dengan CFP yang tidak menemukan hubungan keduanya.

Selain hubungan antara kinerja lingkungan dan pengungkapan lingkungan, beberapa penelitian menguji hubungan antara kinerja lingkungan dan kinerja keuangan. Pengungkapan lingkungan oleh perusahaan dapat dimaknai sebagai goodnews maupun bad news untuk menghindari adverse selection. Perusahaan yang melakukan pengungkapan sosial secara proaktif (sukarela) lebih memiliki kinerja lingkungan yang lebih baik. Dalam pandangan ini investor dan stakeholder lain dianggap akan mempertimbangkan pengungkapan sosial dalam keputusannya. Dengan demikian pengungkapan sukarela yang dilakukan perusahaan, dalam hal ini strategi proaktif, berhubungan dengan kinerja keuangan. Dengan kata lain voluntary disclosure theory memprediksikan bahwa terdapat hubungan positif antara kinerja keuangan dan kinerja lingkungan (Clarkson,et.el,2008).

Terdapat hubungan positif antara environmental performance (EP) pada tingkatan pengungkapan lingkungan dan laporan sosial atau hubungannya dengan web disclosure. 
Dengan kata lain bahwa kinerja lingkungan lebih dapat dijelaskan dengan menggunakan teori pengungkapan sukarela. Hasil yang tidak konsisten mengenai hubungan negatif antara kinerja lingkungan dan pengungkapan yang dilandaskan pada teori politik sosial seperti teori legitimasi dan teori stakeholder. Kedua teori dianggap kurang kuat untuk menjelaskan dan memprediksi pengungkapan sukarela, ketika pengungkapan sosial bersifat voluntary (clarkson, et.al.2008).

Sementara untuk kasus di Indonesia, di mana pengungkapan CSP masih bersifat sukarela, dengan mendasarkan pada hasil penelitian Rofelawati, (2010) bahwa CSP berpengaruh terhadap profitabilitas dan nilai perusahaan.Dengan demikian perlu dipertimbangkan apakah pengungkapan sebagai hal yang mandatory ataukah sebagai sesuatau yang voluntary. Mengingat mandatory yang dituangkan dalam regulasi seharusnya memberikan manfaat bagi investor. Penelitian Poddi \& Vergali(2009) menjelaskan bahwa biaya intangible lebih besar dilakukan oleh perusahaan yang melakukan pengungkapan CSP. Sementara hasil penelitian tersebut menunjukkan bahwa ROE lebih besar dimiliki oleh perusahaan yang secara sukarela mengungkapkan CSP dibandingkan perusahaan yang tidak melakukan pengungkapan.

\section{Tidak Terdapat Hubungan}

Dalam kajian literatur mengenai akuntansi lingkungan yang juga merupakan bagian dari akuntansi sosial terdapat tiga kategori. Pertama penelitian yang mnguji relevansi nilai informasi lingkungan untuk kepentingan investor. Kedua faktor-faktor yang mempengaruhi keputusan manjerial yang berhubungan dengan pengungkapan lingkungan, ketika pengungkapan tersebut bersifat sukarela. Ketiga, penelitian yang menguji hubungan antara kinerja lingkungan dengan pengungkapan lingkungan. Ingram and Frazier (1980) menemukan bahwa tidak terdapat hubungan antara kinerja lingkungan dengan pengungkapan lingkungan. Saat itu menunjukkan bahwa kualitas pengungkapan lingkungan dalam tingkatan yang rendah. Wiseman (1982) menguji hubungan tingkat pengungkapan lingkungan dengan kinerja lingkungan dengan menggunakan proksi yang berbeda yakni sperman rank, yang menujukkan hasil sama yakni tidak terdapat hubungan antara keduanya.

Penelitian di Indonesia yang telah dilakukan dengan mendasarkan pada teori keagenan, legitimasi dan stakeholder menunjukkan bahwa tidak terdapat hubungan antara tingkat pengungkapan CSP dengan kinerja keuangan perusahaan atu CFP ( Sembiring, 2006, Pujiningsih,2009, Fauzi,2007;Fauzi et.al,2010, ). Sementara hasil penelitian Clarkson,et.el 
(2008) menunjukkan bahwa teori politik ekonomi menjelaskan pola data dalam legitimasi yang tidak dapat dijelaskan dalam teori pengungkapan ekonomi.

Terdapat perdebatan manakah hubungan yang lebih mendahului antara CSPdengan CFP. Penelitian Scholtens (2008) menunjukkan bahwa dengan menggunakan model lagged OLS and Granger causation, maka hubungan sebab akibat antara CSP dengan CFP, berawal dari CFP baru kemudian CSP. CFP sering menggunakan proksi ROA dan ROI untuk tujuan jangka pendek perusahaan. Seperti telah banyak ditemukan dalam beberapa penelitian bahwa Asset sebagai bagian formula untuk mengukur kinerja perusahaan (ROA) berhubungan positif dengan CSP. Dengan demikian faktor laba diduga yang sering membedakan hasil hubungan antara CSP dengan CFP.

\section{Strategi Inovasi Perusahaan dan CSP}

Investasi R\& D merupakan strategi perusahaan untuk mencapai keunggulan kompetitif dan secara jangka panjang akan meningkatkan kinerja keuangan perusahaan. Pengeluaran untuk investasi R\& D memberikan kontribusi terhadap CSP. Berdasarkan hasil penelitian Huang lin et.al (2009); Poddi \& Vergali(2009); Hasseldine et al ( 2005); McWilliams dan Siegler (2000) yang menyatakan bahwa terdapat hubungan positif antara CSP dengan CFP yang dikaitkan dengan strategi inovasi perusahaan. Teori signaling yang biasa digunakan untuk menjelaskan reaksi pasar atas informasi baru yang diumumkan perusahaan jarang digunakan untuk penelitian pengungkapan CSP. Teori signaling relevan untuk menjelaskan reputasi perusahaan berkaitan kos kualitas. Hubungan strategi perusahaan dan strategi pengungkapan didasarkan pada kerangka dasar quality signalling (Toms, 2002).

Pengungkapan CSP yang dilakukan oleh perusahaan dapat berupa pengungkapan kualitatif maupun kuantitatif. Signaling theory menekankan pada asimetri informasi di pasar. Dalam teori ini dijelaskan bagaimana asimetri ini bisa dikurangi, dengan memberikan informasi yang lebih sebagai signal. Informasi atau pengungkapan CSP dapat diasumsikan sebagai signal baik oleh perusahaan untuk meningkatkan reputasinya. Pengungkapan kualitatif yang dilakukan perusahaan ditujukan untuk meningkatkan reputasi perusahaan (Toms,2000). Meskipun penelitian ini diakui kurang kredibel karena mengabaikan substansi dari isi pengungkapan, karena tidak menunjukkan jumlah item pengungkapan. Sementara hasil penelitian lain menunjukkan bahwa pengungkapan yang sedikit bisa menyesatkan (Frost and Seamer, 2002). 
Penelitian mengenai hubungan antara pengungkapan CSP dan kinerja keuangan dilakukan oleh Ullmann (1985) dan McWilliams \& Siegel (2001) dengan hubungan yang positif. Hubungan tersebut dimediasi dengan varibel reputasi (Orlitzky et al., 2003). Penelitian lain menunjukkan bahwa terdapat hubungan yang kuat antara reputasi dan kinerja keuangan (Herremans et al., 1993; Roberts and Dowling, 2002; Toms, 2000). Reputasi yang dibungun perusahaan dilakukan dengan penggunaan sumber daya perusahaan khususnya yang menyangkut departemen research and develompent (R\&D). Departemen ini yang memberi kontribusi besar terhadap reputasi perusahaan dalam memenangkan persaingaan yang berkelanjutan.

Penelitian Pujiningsih (2009) menunjukkan bahwa perusahaan di Indonesia pada periode 2003-2006 yang terdaftar di BEI melakukan pengungkapan CSP bergantung pada kondisi keuangan perusahaan. Dalam hal ini size perusahaan yang diproksi dengan total aset menunjukkan hubungan yang positif antara size perusahaan dengan tingkat pengungkapan sosial, hal ini konsisten dengan penelitian Angraini, (2007), Sembiring (2006) ; Fauzi (2007) dan Rofelawati (2010). Senada dengan hasil penelitian yang dilakukan Toms (2002) yang menggunakan pendekatan Resource Based View (RBV). Dengan pendekatan ini dapat dijelaskan bahwa reputasi yang dibangun oleh perusahaan bergantung dari posisi keuangnan perusahaan. Dengan demikian menurut Hasseldine et al ( 2005) bahwa belanja research and development $(\mathrm{R} \& \mathrm{D})$ dan diversifikasi perusahaan untuk tujuan kebermanfaatan persaingan atau competitive adventage juga merupakan variabel yang mempengaruhi tingkat pengungkapan lingkungan.

Penelitian Toms (2002) menunjukkan hubungan positif antara reputasi dan pengungkapan CSP dengan variabel kontrol ukuran perusahaan, kelompok industri, risiko sistematis, kepemilikan isntitusional. Sementara dengan teori signaling hasil penelitian Hasseldine (2005) menunjukkan bahwa pengungkapan CSP secara kualitatif lebih kuat pengaruhnya terhadap investor dibandingkan dengan pengungkapan kuantitatif. Selain itu belanja R\&D dan diversifikasi sebagai proksi strategi perusahaan berpengaruh terhadap reputasi lingkungan perusahaan.

Strategi lain yang berhubungan dengan perilaku etis perusahaan termasuk tanggung jawab sosial digunakan untuk pencapaian reputasi yang baik. Menurut Fombrun, Gardberg \& Barnett dan Peloza (Gaia Soana,2006) agar perusahaan lebih memiliki tanggung jawab sosial perusahaan, maka perusahaan tidak hanya menyediakan insentif bagi para pelaku pasar, melainkan juga bagi seluruh stakeholder lain. Hal ini dilakukan untuk 
mempertahankan reputasi, termasuk untuk mengurangi kemungkinan yang tidak dapat diprediksi seperrti penarikan produk yang akan mengancam profitabilitas perusahaan.

Variabel R\&D expense yang merupakan proksi dari intangible assets berpengaruh positif terhadap CFP dan CSP McWilliams dan Siegler (2000). Belanja ini berkaitan dengan inovasi dan pengembangan perusahaan yang dapat mempengaruhi pertumbuhan ekonomi jangka menengah. Oleh karena belanja R\&D tidak secara langsung berhubungan dengan tingkat profitabilitas dalam jangka pendek. Hasil ini konsisten dengan penelitian Huang lin et.al (2009). Dengan mendasarkan pada hasil penelitian Huang lin tersebut dalam penelitian ini mencoba untuk menemukan bukti empiris apakah investasi R\&D yang akan mempengaruhi CSP dan secara jangka panjang akan berpengaruh terhadap CFP yang sebelumnya belum dilakukan untuk konteks jangka panjang.

Penelitian Scholtens (2008) menunjukkan bahwa dengan menggunakan model lagged OLS and Granger causation, maka hubungan sebab akibat antara CSP dengan CFP, berawal dari CFP baru kemudian CSP. Dengan demikian hal ini berkaitan dengan ketersediaan dana untuk aktivitas sosial. Dengan demikian variabel belanja R\& Develompen dalam hal ini sangat penting untuk memahami hubungan antara CSP dan CFP. Dengan mendasarkan pada penelitian ini maka penelitian ini menggunakan variabel belanja R\&D sebagai variabel yang berpengaruh terhadap CSP.

Penelitian Lopez-Perez et.al (2007) menunjukkan bahwa manajer memasukkan isu CSP sebagai suatu strategi korporasi untuk keunggulan kompetitif dan profitabilitas. Hasil dari penelitian ini adalah praktik inovasi perusahaan dipengaruhi oleh strategi CSP. Inovasi sebagai bagian penting dalam keunggulan kompetitive selalu dikaitkan dengan kebijakan CSP. Sebagai contoh, kebijakan CSP diarahkan untuk adopsi teknologi baru yang berkaitan dengan peningkatan kualitas produk serta aspek lingkungan. Kualitas produk akan berdampak pada profitabilitas perusahaan. Sedangkan aspek lingkungan dapat dilihat dari perspektif teori legitimasi maupun teori stakeholder dalam rangkan keberlangsungan usaha. Hasil penelitian ini menunjukkan hubungan antara pengungkapan CSP dengan inovasi perusahaan dalam hal ini berkaitan dengan belanja R\& D.

Dengan mendasarkan pada teori stakeholder penelitian yang dilakukan oleh Duhe (2009) menjelaskan bahwa hubungan reputasi perusahaan dan triple bottom line. Dengan menganalisis 706 perusahaan di Amerika Serikat selama 21 yang memiliki atribut reputasi perusahaan berupa kualitas manajemen, kinerja finansial dan tanggung jawab sosial memiliki hubungan yang positif dengan kinerja keuangan. Reputasi perusahaan digali melalui persepsi insider perusahaan yang terdiri dari eksekutif,direktur, dan analis 
keuangan. Implikasi dari hasil penelitian ini bahwa reputasi manajemen ditentukan oleh kualitas manajemen, kemampuan financial serta pengelolaan CSP akan dijadikan pertimbangan bagi investor dalam pengambilan keputusan.

Investasi R\& D merupakan strategi perusahaan untuk mencapai keunggulan kompetitif dan secara jangka panjang akan meningkatkan kinerja keuangan perusahaan. Pengeluaran untuk investasi R\& D memberikan kontribusi terhadap CSP. Berdasarkan hasil penelitian Huang lin et.al (2009) Penelitian Poddi \& Vergali(2009); Hasseldine et al ( 2005); McWilliams dan Siegler (2000); Lopez-Perez et.al (2007) ; Scoltens (2008). yang menyatakan bahwa terdapat hubungan positif antara CSP dengan CFP yang dikaitkan dengan strategi inovasi perusahaan. Dari beberapa hasil penelitian tersebut bahwa variable investasi R\&D berhubungan positif ditinjau dari teori signaling.

Landasan teori selain teori signaling yang digunakan dalam penelitian pengungkapan CSP antara lain teori ekonomi $($ Gray,1995) sebagai kritik atas lemahnya landasan teori dalam penelitian yang dilakukan Ullmann (1985), teori akuntansi postif oleh Milne ( 2002), dan teori legitimasi oleh Milne (2002). Teori-teori ini digunakan untuk menjelaskan perilaku manajer dalam melakukan pengungkapan CSP apakah untuk menghindari kos politik yang lebih besar ataukah untuk mempertahankan maupun mendapatkan legitimasi.

\section{Biaya Modal dan CSP}

Pengungkapan CSP dapat digunakan untuk mengurangi asimetri informasi dan risiko. Richardson et al. (1999) menjelaskan hubungan antara biaya modal atau cost of capital dengan pengungkapan CSP. Menurutnya pengurangan risiko dan asimetri informasi akan mempengaruhi kinerja keuangan perusahaan. Jika aktivitas sosial perusahaan dianggap relevan untuk menilai prospek perusahaan, maka aktivitas tersebut berdampak pada aktivitas keuangan. Selain itu Green Funds and Ethical Investing (Reyes \&Grieb, 1998) menjelaskan bahwa periklanan yang memasukkan dimensi sosial dapat digunakan untuk melegitimasi perusahaan dimata konsumen dan hal tersebut memberikan kontribusi untuk kesuksesan produk perusahaan.

Bukti penelitian empiris lain menujukkan bahwa terdapat hubungan negatif antara biaya modal dengan pengungkapan CSP Epstein (2000). Namun sebaliknya Richardson dan Welker (2001) menemukan hubungan positif antara keduanya. Biaya modal yang lebih rendah untuk perusahaan yang melakukan pengungkapan CSP akan memiliki kinerja finansial yang lebih tinggi. Sejalan dengan Paul \& Siegel (2006) bahwa CSP mungkin akan 
berpengaruh terhadap efisiensi, perubahan teknik dan skala ekonomi juga akan berpotensi meningkatkan outsourcing serta pengurangan tenaga kerja dan investasi.

Pengungkapan laporan keuangan dapat disetarakan dengan pengungkapan CSP, bahwa pengungkapan CSP akan mengurangi biaya modal dan mengurangi biaya transaksi saham. Keduanya tersebut dapat mempengaruhi kinerja pasar saham. Pengungkapan CSP berpengaruh secara langsung melalui preferensi investor, jika investor bersedia menerima return yang lebih rendah dari investasinya pada perusahaan yang memenuhi CSP. Hasil penelitian menujukkan bahwa terdapat hubungan negatif antara biaya modal dengan pengungkapan CSP Epstein (2000). Namun sebaliknya Richardson dan Welker (2001) menemukan hubungan positif antara keduanya. Biaya modal yang lebih rendah untuk perusahaan yang melakukan pengungkapan CSP memiliki kinerja finansial yang lebih tinggi.

Richardson et al. (1999) menjelaskan hubungan antara biaya modal atau cost of capital dengan pengungkapan CSP. Pertama pengungkapan CSP dapat mengurangi asimetri informasi atau risiko. Pengurangan risiko dan asimetri informasi akan mempengaruhi kinerja keuangan perusahaan. Jika aktivitas sosial perusahaan dianggap relevan untuk menilai prospek perusahaan, maka aktivitas tersebut berdampak pada aktivitas keuangan. Selain itu Green Funds and Ethical Investing (Reyes \&Grieb, 1998) menjelaskan bahwa periklanan yang memasukkan dimensi sosial dapat digunakan untuk melegitimasi perusahaan dimata konsumen dan hal tersebut memberikan kontribusi untuk kesuksesan produk perusahaan

Menurut Paul \& Siegel (2006) bahwa CSP mungkin akan berpengaruh terhadap efisiensi, perubahan teknik dan skala ekonomi juga akan berpotensi meningkatkan outsourcing serta pengurangan tenaga kerja dan investasi. Selain itu bahwa motivasi manajer dalam melakukan pengungkapan sosial bergantung pada undang-undang pajak, lokasi, umur aktiva tetap serta aktivitas inovasi. Dari hasil penelitian terdahulu tersebut dapat disimpulkan bahwa CSP dapat meningkatkan efisiensi perusahaan termasuk efisiensi biaya modal.

Motivasi regulator yang mewajibkan dilakukannya pengungkapan dalam laporan keuangan akan memberikan manafaat bagi investor karena akan meningkatkan transparansi dan mengurangi asimetri informasi. Pengungkapan yang dilakukan oleh perusahaan seharusnya memberikan manfaat untuk pengurangan biaya modal. Hal ini dengan alasan bahwa peningkatan pengungkapan akan mengurangi biaya transaksi untuk investor, karena tingkat likuiditas yang lebih besar dalam pasar serta lebih besarnya 
permintaan atas surat berharga perusahaan (Diamond \& Verrecchia, 1991). Selain itu pengungkapan akan mengurangi risiko dan ketidakpastian return saham, demikian hasil penelitian (Clarkson,Guedes, \& Thompson, 1996 ( Richardson dan Welker,2001).

Hasil penelitian di Indonesia menunjukkan bahwa nilai pasar perusahaan tidak berhubungan dengan CSP (Andayani et.al,2008). Berbeda dengan hasil penelitian Rofelawati (2010) yang menyatakan terdapat hubungan positif antara nilai perusahaaan dengan reputasi CSP. Berkebalikan dengan ini, hasil penelitian hubungan CSP dengan kinerja pasar juga oleh Arx dan Ziegler (2008) menunjukkan terdapat hubungan yang negatif antara CFP dengan CSP. Hasil penelitian lebih lanjut disarankan untuk menggunakan faktor lain yakni likuiditas saham sebagai variabel kontrol untuk menjelaskan hubungan keduanya. Likuiditas saham dapat dijadikan faktor yang menjelaskan hubungan CSP dengan CFP sesuai dengan teori good management, yang menyatakan bahwa CSP dapat mengurangi biaya modal.

\section{Kinerja Pasar dan CSP}

Hubungan antara kinerja pasar perusahaan dengan CSP menunjukkan hasil yang beragam. Penelitian Deegan (2004) menunjukkan bahwa pemeringkatan TRI/Toxic Release Inventory direspon negatif oleh pasar. Pemeringkatan ini dianggap sebagai bad news bagi pelaku pasar. Penelitian di Italia menunjukan bahwa harga pasar saham tidak dipengaruhi oleh pengungkapan CSP(Veori et.al,2010). Penelitian di Indonesia juga menunjukkan bahwa kinerja pasar tidak berhubungan dengan CSP (Andayani e.al,2008). Berbeda dengan ini, hasil penelitian Rofelawati (2010) menunjukkan bahwa CSP berhubungan dengan nilai pasar perusahaan.

Lajili dan Zeghal pada tahun 2006 (Sayekti dan Wodanbio,2007) menemukan bahwa perusahaan yang lebih banyak mengungkapkan informasi human capital (yang juga merupakan bagian dari CSP) memiliki kinerja pasar yang lebih baik dibandingkan dengan perusahaan yang lebih sedikit mengungkapkan informasi tersebut. Penelitian lain menujukkan terdapat hubungan positif antara CSP dengan kinerja pasar perusahaan (Downing,1997;Poddi \& Vergali,2009).

Apakah pengungkapan sosial direspon oleh pasar? Pertanyaan ini muncul seiring dengan pertanyaan apakah pasar memerlukan pengungkapan sosial? Beberapa hasil penelitian menunjukkan bahwa terjadi peningkatan permintaan pasar atas pengungkapan sosial. Freedman and Patten (1989) yang menguji reaksi pasar atas pengungkapan sosial. Saat itu telah muncul konsep baru mengenai stakeholder yang lebih luas dibandingkan 
dengan shareholder. Sementara Deegan and Rankin (1997) Business in the Environment (1994) menemukan bahwa pengungkapan sosial merupakan informasi yang tidak relevan bagi investor. Sebaliknya berdasarkan survey yang dilakukan oleh University of Cambridge (2003) terhadap para CEO menunjukkan bahwa manajer mengagangap penting pengungkapan sosial. Pengungkapan tersebut sebagai alat untuk mnjaga kredibilitas sosial dan menciptakan citra positif perusahaan.

Ernst and Young (2002) melakukan survei terhadap manajer senior, yang menyatakan bahwa etika perusahaan dan perilaku sosial dan lingkungan merupakan hal penting yang berdampak pada kepentingan bisnis. Sebesar $70 \%$ konsumen bank mempertimbangkan aspek CSP dalam pembelian produk konsumen. Penelitian yang dilakukan oleh Deni Greene Consulting Services (2001) menunjukkan bank sebagai pelaku pasar mayoritas mempertimbangkan pengungkapan sosial dan lingkungan. Lebih lanjut Ernst and Young (2003) menemukan bahwa 61\% pelaku industri keuangan menganggap bahwa isu lingkungan sangat penting bagi analis investasi. Manajer keuangan juga meminta informasi kinerja lingkungan . selain itu Deni Greene Consulting Services (2002) menunjukkan hasil penelitian bahwa industri perbankan mengalami peningkatan permintaan mengenai pengungkapan sosial dan lingkungan. Hubungan positif CSP dengan return saham juga dilakukan oleh Posnikoff (1997), Moskowitz (1972) dan Poddi \& Vergali ( 2009). .

Peningkatan konsumsi atas produk perusahaan menjadi daya tarik tersendiri bagi preferensi investor. Hal ini dapat dijadikan rasionalisasi hubungan antara pengungkapan CSP dan preferensi investor. Sebagai contoh Downing (1997) melaporkan bahwa manajer dari suatu lembaga dana pensiun menyatakan bahwa investor tertarik dengan informasi pengungkapan sosial. Dengan hasil ini dapat dikatakan bahwa investor mempertimbangkan pengungkapan sosial dalam pengambilan keputusannya.

Sementara hasil lain menunjukkan, bahwa tidak terdapat hubungan antara return saham dan pengungkapan sosial untuk jangka pendek. Sementara untuk data longitudinal terdapat hubungan yang konsisten bahwa semakin rendah (tinggi) return saham, semakin rendah(tinggi) pengungkapan sosial. Tidak terdapat satu teori yang menjelaskan hubungan ini. Hal ini dianggap sebagai good management yang menjadi signal. Hal ini diperkuat dengan hasil penelitian Vance (1975) yang menunjukkan bahwa tingkat pengungkapan yang tinggi akan mempengaruhi penurunan harga saham relatif terhadap rata-rata pasar (Preston and O'Bannon, 1997). Menurut hipotesis ini dalam kaitannya dengan aktivitas 
pasar modal dapat dijelaskan bahwa terdapat hubungan negatif antara tingkat pengungkapan sosial dengan harga saham.

Penelitian mengenai hubungan CSP dengan harga pasar saham di italia menunjukan bahwa harga pasar saham tidak dipengaruhi oleh pengungkapan CSP(Veori et.al,2010). Dengan demikian dapat dijelaskan bahwa informasi sosial tidak dipertimbangkan oleh investor dalam pengambilan keputusan. Implikasi dari penelitian ini adalah bahwa pengungkapan sosial tidak diperlukan oleh investor. Jika informasi pengungkapan sosial dan lingkungan merupakan informasi yang relevan bagi investor, maka dasar inilah yang biasanya digunakan oleh regulator dalam menetapkan regulasi,

Corporate governance sebagai salah satu faktor penentu CSP perusahaan (Blomback\& Wigen,2008). Hasil penelitian yang dilakukan Andayani et.al (2008) menunjukkan bahwa kepemiklikan institusional, market capitalization, komite auidit, utang dan penjualann tidak berhubungan dengan peringkat CSP. Sementara komisaris independen berhubungan positif dengan CSP. Hal ini menunjukkan bahwa perusahaan yang memiliki komisaris independen memiliki kinerja CSP yang lebih baik. Hasil sedikit berbeda dengan penelitian Pujiningsih (2009) dengan menggunakan perusahaan yang tergabung dalam Sri-Kehati Index, dimana GCG yang diproksi oleh komisaris independen, dan kepemilikan institusional tidak berpengaruh signifikan terhadap pengungkapan sosial. Dengan demikian kepemilikan institusional, komite audit tidak dapat membuktikan teori keaganan sebagai dasar pengungkapan sosial, bahwa pengungkapan sosial akan dapat mengurangi asimetris informasi.

Penelitian Lang dan Lundholm tahun 1993 (Widiastuti,2002) mengenai pengungkapan sukarela menunjukkan bahwa tingkat pengungkapan yang lebih tinggi berasosiasi dengan kinerja pasar yang lebih baik (yang diukur dengan return saham). Lajili dan Zeghal pada tahun 2006 (Sayekti dan Wodanbio,2007) menemukan bahwa perusahaan yang lebih banyak mengungkapkan informasi human capital (yang juga merupakan bagian dari CSR) memiliki kinerja pasar yang lebih baik dibandingkan dengan perusahaan yang lebih sedikit mengungkapkan informasi tersebut. Pendekatan yang digunakan untuk mengukur information value dari informasi human capital dalam penelitian tersebut adalah financial portfolio performance approach.

Pelaku pasar didorong untuk tidak melakukan pengungkapan sosial yang positif sebagai pengganti dari reaksi negatif dari pasar atas pemeringkatan oleh TRI/ Toxic Release Inventory (Deegan,2004). Pemeringkatan ini dianggap sebagai bad news bagi pelaku pasar. Hasil penelitian di Indonesia menunjukkan bahwa pemeringkatan CSP tidak berpengaruh 
terhadap nilai pasar saham (Andayani,et.al,2008). Berbeda dengan hasil penelitian Rofelawati (2010) yang menunjukkan bahwa reputasi CSP perusahaan berpengaruh positif terhadap nilai perusahaan.

\section{SIMPULAN}

Dari uraian di atas, dapat disimpulkan bahwa hubungan negatif antara CFP dengan CSP mendasarkan pada teori : 1) trade off hypotesis, yang didasarkan pada pemikiran neoklasik; 2) managerial opportunism, yang mendasarkan pada teori akuntansi positif dan 3) teori legitimasi, yang mendasarkan pada teori kontrak sosial. Sementara itu, hubungan positif antara CFP dengan CSP dapat ditinjau dari perspektif : 1) teori good management, atau yang biasa disebut sebagai social impact hypotesis; 2) teori scarce resources ;3) teori stakeholder dan 4) voluntary disclosure theory. Hubungan variable strategi inovasi perusahaan dengan CSP dapat dijelaskan dengan menggunakan teori signaling, tujuan CSP yaitu untuk meningkatkan reputasi perusahaan. Hubungan anatara biaya modal dengan CSP dapat dijelaskan dengan menggunakan teori good management, tujuan CSP yaitu untuk meningkatkan efisiensi. Hubungan kinerja pasar dengan CSP dijelaskan dengan teori good management dan signaling, CSP merupakan good news atau bad news bagi pasar.

\section{DAFTAR PUSTAKA}

Arx. Urs von and Ziegler.Andreas.2008.The Effect of CSP on Stock Performance: New Evidence for the USA and Europe.

Andayani, Wuryan \& Atmini, Sari dan Sadewo, Dede, Wangi.2008. Corporate Social Responsibility, Good Corporate Governance And The Intellectual Property: An External Strategy Of The Management To Increase The Company's Value, Makalah pada National Conference on Management Research 2008Makassar, 27 November

Anggraini, Reni, 2007, Pengungkapan Informasi Sosial dan Faktor-faktor yang Mempengaruhi Pengungkapan Informasi Sosial dalam Laporan Keuangan Tahunan (Studi Empiris pada Perusahaan yang Terdaftar di BEJ, SNA Padang 23-26 Agustus

Bassen, Alexander \& Kovács Ana Maria.2008.Environmental, Social and Governance Key Performance Indicators from a Capital Market Perspective. 182-192

Becchetti, Leonardom\& Ciciretti, Rocco \& Hasan Iftekhar,2009. Corporate social responsibility and shareholder's value: an empirical analysis Bank of Finland Research. Discussion Papers 
Beardsell, Julie, 2008.The influence of CSP disclosure

Brancoa, Manuel Castelo dan Rodriguesb Lu' cia Lima.2008. Social responsibility disclosure: A study of proxies for the public visibility of Portuguese banks.The British Accounting Review 161-181

Barnett, Michael L.2005. Stakeholder Influence Capacity And The Variability Of Financial Returns To Corporate Social Responsibility.Academy of Management Review,October

Cormier,Denis.2009.The Informational Contribution of Social and Environmental Disclosures for Investors corporate governance and company. april

Campbell, David. 2004.A longitudinal and cross-sectional analysis of environmental disclosure in UK companies - a research note The British Accounting Review107-117

Fauzi, Hasan. Mahoney, Louis dan Rahman, A.A.2007. Institutional Ownership and Corporate Social Performance : Empirical Evidence From Indonesian Companies. Issues in Social and Environmental Accounting. Vol 1. No.2 Desember

Gaia Soana, Maria.2008. The relationship between corporate social performance and corporate financial performance, Electronic copy available at: in the banking sector ,http:// ssrn.com/abstract $=1325956$

Fauzi Hasan, Mahoney,Lois S. \& Rahman.Azhar Abdul.2007 The Link between Corporate SocialPerformance and Financial Performance: Evidence from Indonesian Companies

Fauzi, Hasan.2008. Corporate Social and Financial Performance: Empirical Evidence from American Companies

Fauzi Hasan, Mahoney,Lois S. \& Rahman.Azhar Abdul.2007 The Link between Corporate Companies SocialPerformance and Financial Performance: Evidence from Indonesian

Fauzi, Hasan.2008. Corporate Social and Financial Performance: Empirical Evidence from American Companies

Haniffa, R.M., dan T.E. Cooke (2005), “The Impact of Culture and Governance on Corporate Social Reporting", Journal of Accounting and Public Policy 24, pp. 391-430.

Heal,Geoffrey \& Garret,Paul .2004. Corporate Social Responsibility . An Economic and Financial Framework. This paper was prepared for presentation at the 2004 Annual Conference of the Monte Paschi Vita, organized around the topics of corporate governance and corporate social responsibility

Hasseldinea J., A.I. Salamab, J.S. Tomsc.2005. Quantity versus quality: the impact of environmental disclosures on the reputations of UK Plcs.The British Accounting Review 231-248

Huang Lin ,Chin-a,2009 The impact of corporate social responsibility on financial performance: Evidence from business in Taiwan, Technology in Society 56-63 
Hastuti, Theresia, 2005, Hubungan Antara Good Corporate Governance Dan Struktur Kepemilikan Dengan Kinerja Keuangan (Studi Kasus pada Perusahaan yang listing di Bursa Efek Jakarta), SNA, Solo

Lopez-Perez,M. Victorio, Perez-Lopez, M Carmen, Redriguez-Ariza, Lazaro, 2007. The Opinions of European Companies on Corporate Social Responsibility and Its Realition to Innovation. Social and Environmental accounting Journal. Vol 1. No 2. Hal 276-295

Pujiningsih Sri 2009 Analisis Pengaruh Mekanisme GCG terhadap pengungkapan sosial dan kinerja operasi (studi empiris pada perusahaan yang termasuk dalam sri-kehati index), Laporan Penelitian Kelompok, Lemlit UM

Pujiningsih Sri 2009,2009, Manajemen Laba dan Karakteristik Perusahaan yang Melakukan Pengungkapan Sosial (Studi Empiris pada BEI Periode 2003-2006), Laporan Penelitian Fundamental, Lemlit UM

Makni,Rim ; Francoeur,Claude \&Bellavance, Franc,ois,2008. Causality Between Corporate Social Performance and Financial Performance: Evidence from Canadian Firms Journal of Business Ethics _ Springer

Mackey,Alison.2008. Corporate Social Responsibility And Firm Performance: Investor Preferences And Corporate Strategies Academy Of Management Review

Poddi, Laura \& Vergalli, Sergio.2009. Does Corporate Social Responsibility Affect the Performance of Firms? Paper disampaikan pada EACES Conference University of Perugia, June, 25 - 27

Richardson.Alan J dan Welker, Michael,2001.Social disclosure, financial disclosure and the cost of equity capital.. Accounting, Organizations and Society 26 597-616

Rofelawati, Budi,2010. Analisis Determinan Tingkat Pengungkapan Lingkungan dan dampaknya terhadap Reputasi dan Nilai Perusahaan (Studi pada Industri Manufaktur yang terdaftar di BEI). Ringkasan Disertasi disampaikan pada ujian Akhir Dosertasi program Doktor Ilmu Akuntansi, Universitas Brawijaya Malang

Richardson, Alan J \& Welker,Michael.2001. Social disclosure, Financial Disclosure And The Cost Of Equity Capital.Accounting Organization and Society

Sembiring,Edi R, 2005.Karakteristik Perusahaan dan Pengungkapan Tanggung Jawab Sosial Perusahaan ; Studi Empiris di Bursa Efek Jakarta, Makalah ,SNA VIII Solo, 15-16

Sayekti Y dan Wondanbio, L,S,2007, Pengaruh Csr Disclosure Terhadap Earning Response Coefficient (Suatu Studi Empiris Pada Perusahaan yang Terdaftar Di Bursa Efek Jakarta)

Toms, J. S. 2002. Firm Resources, Quality Signals And The Determinants Of Corporate Environmental Reputation:Some Uk Evidence. British Accounting Review

Siegel, Donald S dan Vitaliano Donald F, 2006.An Empirical Analysis of the Strategic Use of Corporate Social Responsibility,JEMS 
Scot, Jason, 2005,Strategic Use Of CSP As A Signal For Good Management

Scholtens, Bert .2008.A note on the interaction between corporate social responsibility and financial performance.Elsevier

Widiastuti, Harjanti (2002), "Pengaruh Luas Ungkapan Sukarela dalam Laporan Tahunan terhadap Earning Response Coefficient (ERC)", Simposium Nasional Akuntansi V, Semarang 5-6 2003 